\title{
Analysis of concrete applied after prolonged mixing time
}

\author{
Charles Ferreira de Oliveira ${ }^{1}$, Gabriel Henriques Rabelo Gouvêa ${ }^{2}$, Luiz Antônio Melgaço Nunes Branco ${ }^{3}$ \\ ${ }^{1}$ Master in Civil Construction, UFMG, Departamento de Engenharia de Materiais e Construção Civil, Belo Horizonte. Brazil, charles \\ ${ }^{2}$ M.Sc Student, FUMEC, Mestrado Profissional em Processos Construtivos e Materiais de Construção, Belo Horizonte. Brazil \\ ${ }^{3}$ Professor Doctor, UFMG, Departamento de Engenharia de Materiais e Construção Civil, Belo Horizonte. Brazil \\ Correspondence Author: Gabriel Henriques Rabelo Gouvêa, M.Sc Student, FUMEC, Mestrado Profissional em Processos Construtivos e Materiais de \\ Construção, Belo Horizonte. Brazil. \\ E-mail:- gabrielhrg.ep@gmail.com.
}

Received date: 15 August 2019, Accepted date: 30 September 2019, Online date: 22 November 2019

Copyright: (C) 2019 Charles Ferreira de Oliveira et al, This is an open-access article distributed under the terms of the Creative Commons Attribution License, which permits unrestricted use, distribution, and reproduction in any medium, provided the original author and source are credited.

\begin{abstract}
The Brazilian Standard NBR - "Norma Brasileira" 7212 (ABNT - "Associação Brasileira de Normas Técnicas”, 2012) recommends that ready mixed concrete, transported by mixer truck for longer than $\mathbf{1 . 5}$ hours, must be refused by the user. It also advises that concrete shall not be released and thickened in a period exceeding 2.5 hours after the addition of water to the mixture, considering such concrete as overdue. It is common to see delays in concrete operations, so it is important to know the main properties of concrete used after prolonged mixing time. Further more, material waste is a worldwide problem and concrete is significantly wasted in construction activities. This study tests the hypothesis of using concrete after prolonged mixing time and aims to evaluate changes in key properties of a concrete dosed with Portland cement Type III (ASTM - American Society for Testing and Materials), mixed during 4 hours without the use of setting time retardant, hourly assessing changes in workability, stiffness, compressive strength and corrosion potential. Resonant frequency, electrical volumetric resistivity and compressive strength tests were performed. The results showed that even with the use of superplasticizer, there was great loss of concrete slump. It was also noted an increasing tendency of the dynamic modulus of elasticity and a decreasing tendency of the electrical resistivity of the concrete, but there was no significant loss in strength during the assessment time. Even though resistivity shows that the higher the mixing time, the greater will be the propensity of concrete not to protect the reinforcement bars, it is concluded that it is still possible to use concrete after the mixing time recommended by NBR 7212: 2012 and this way reduce material waste in civil construction.
\end{abstract}

Keywords: Overdue Concrete. Prolonged Mixing. Concrete Properties

\section{INTRODUCTION}

The mixture called concrete forms one of the most used materials in the world. This is due to its ease in preparation, use and the achievement of excellent performance after its application, although it is not found ready in nature. Concrete may be easily fabricated by mixing materials such as cement, sand, gravel and water, which may still get additions and/or additives as required improvement or enhancement in some property. After being prepared, in the fresh state, it may be cast into molds to be shaped by the user and, as it hardens, it gets the desired strength and form, at which time should be demolded.

According to Urban and Sicakova (2018), mixing and delivery can negatively influence the homogeneity and uniformity of concrete mixtures, leading to effects on technical parameters such as workability, longer-term proceedings and performance characteristics of concrete.

At construction sites, due to lack of free space for large materials storages and the need to maximize yields and promote waste reduction, an increase of the use of concrete produced in concrete batching plants has been noticed daily. The ready-mixed concrete, also known as concrete dosed in batching plants, is a type of material produced with higher technological quality control, in which production is carried out with greater precision, monitoring the number of constituent materials of the mixture to meet the most varied types of works. They can also be produced on a larger scale, thus favouring the increase in productivity of worksites and providing conditions to achieve high resistance with the use of additives and additions.

The ready mixed concrete has the great advantage of being guaranteed by the supplier concerning security and the attainment of the specified characteristic strength (fck) for elements of the work. This is due to greater technology control in production, being expected that the quality of concrete is greater than mixed on site, but some care should be taken in receiving concrete: at 
arrival, it is important that the responsible staff check if the cement truck has arrived sealed and if there is correspondence between the seal code and the code on the invoice; one must check the truck's departure time from the plant as well as if the volume and the strength of the concrete received are in accordance to the request made, because due to a large number of requests received by the plants of different works and several distinct features, there is the possibility that the wrong truck come by mistake to the site and if this concrete is used outside of the planned project parameters, it can cause serious future problems. It is also important, after the conference of the sealing, to make the assessment of the concrete consistency through the slump test and the collection of samples with the purpose of running resistance control trials (preparation of specimens); Finally, it is important to map the areas of concrete made by each individual shipment that arrives at work, as (PEREIRA, 2017).

Although there is a Brazilian standard that recommends that the ready-mixed concrete, transported by mixer truck, shall not be released and thickened in a period exceeding two hours and a half after the addition of water or one hour and a half after the start of transportation, it is observed that in large urban centres and even in remote areas, delays in the cast of concrete are still common to experience at construction sites due to numerous factors such as problems in shifts, traffic, access, shoring and openings of moulds, among others. Erdogdu (2005) states that 90 minutes seems to be a turning point related to proper placement, campaction and subsequent operations of concrete.

The objective of this study is to evaluate the changes in the main properties of a concrete dosed with Portland cement Type III (high early strength) over 4 hours stirring, without the use of setting time retardant additive, hourly assessing changes in workability, stiffness, compressive strength and corrosion potential.

Thus, this work is justified by the need to know the main concrete properties when dosed with superplasticizer, without setting time retardant and further water addition during up to 4 hours mixing, as in routine practice the concrete is still used, even if the time is above recommended by the NBR 7212 (ABNT, 2012). To this end, results in dynamic modulus of elasticity, compressive strength and specific electrical resistivity tests are analyzed, besides the evaluation of consistency loss in the course of prolonged mixing.

\section{LATE CAST CONCRETE}

According to Araujo et al. (2017), due to the hydration action of cement compounds, the concrete used after setting time is considered overdue. In prolonged mixing concrete production, it is not always possible to control the start of cement setting, especially if the setting time retardant additive is unused. It is thus important to be careful not to add water to the mixture over the amount provided in dosage since excessive water addition can cause exudation and/or segregation of the mixture, as well as decrease mechanical strength. Prolonged mixing concretes tend to lose water to the environment during agitation creating a tendency to become less plastic due to rapid loss in a slump. To minimize this kind of problem, plants use plasticizer and superplasticizer additives which contribute to better concrete plasticity without property loss.

According to Baskoca et al. (1998), prolonged mixtures may often be experienced in the concrete industry, especially to meet the longer delivery distances or cast delays due to problems on site. Although the mixing time is also limited by the American standard to 1 hour and a half (ASTM C94, 2019), this time is exceeded quite often, especially when using the setting time retardant additives. If water is not added to the mixture, in addition to established at the initial dosage, no adverse effects arise on prolonged mixing of structural concrete, however, if the water is added to the mixture it causes the decrease of the provided strength of the concrete.

It can be also stated that a prolonged mixture will lower plasticity observed during mixing and this is possibly related to at least three reasons: the insufficient amount of water initially placed; higher rate of evaporation or absorption of water by dry aggregates and higher hydration rate. When water is added to compensate the loss of plasticity caused by the first two reasons, there is no loss of strength, but adding extra water to combat the last reason leads to a loss of mechanical strength of the concrete. For Rahman et al. (2011), adding water to prolonged mixture to maintain the initial plasticity causes little change in the concrete permeability category, but there is significant strength loss (tensile and compressive), as well as increased water absorption and these losses tend to increase almost linearly with increasing mixing time, further showing that over concrete mixing time, adding water causes the increase of the water/binder factor, contributing to the expansion of concrete pores, which motivates the increased water absorption and provides increased permeability of chloride ions.

The NBR 7212 (ABNT, 2012) sets out the requirements for the execution of ready mixed concrete, storage of materials, dosage operations, mixing, quality control, transportation, inspection, as well as the acceptance or rejection criteria of the internal control of the batching plant, in which is recommended that plant dosed concrete transported by mixer truck, is not released after 2 and a half hours from the first water addition or after 1 hour if transported by equipment without agitation. With this proposition, the norm implies that if delays occur in delivery for any reason, the concrete quality may be compromised.

\section{CONCRETE PROPERTIES}

There are many important properties to be observed in concrete used in construction, which can be evaluated in its fresh state (when the concrete is freshly mixed, still in plastic state, ie, the ability to be molded) and its hardened state (when it dries and gains resistance). After the completion of the concrete mixture it is possible to evaluate some of its properties, and the main characteristics of concrete at this stage are: density, cohesion, plasticity, exudation, segregation, incorporated air content, among others; in the cured state, it is possible to evaluate the compressive strength, tensile strength, penetration resistance, abrasion resistance, permeability, resistivity, modulus of elasticity, absorption, density, hardness, cement content, among others. This work 
concentrates studies to evaluate plasticity, density, compressive strength, dynamic modulus of elasticity and electrical resistivity of concrete.

\subsection{Plasticity}

It is understood by plasticity the greater or lesser ease of molding or compaction of concrete in a manner to remove the largest possible number of voids from the mixture. It can be technically defined as the amount of work required to fully compact the concrete while maintaining homogeneity and may depend on the particle size of the aggregates, the use of additives and the water/binder factor and assessed for their ease of molding and compaction during cast.

\subsection{Density}

According to Mehta and Monteiro (2008), the concrete, due to its density, can be classified into three categories: lightweight concrete, when its density is below $1800 \mathrm{~kg} / \mathrm{m}^{3}$, can be composed of natural, lightweight or synthetical aggregates and is more commonly used in elements that emphasize lightness; Normal concrete, when its density is in the range of $2400 \mathrm{~kg} / \mathrm{m}^{3}$, can be composed of natural sand and gravel or crushed rock and is more commonly used in overall structure; and heavy concrete, when density is greater than $3200 \mathrm{~kg} / \mathrm{m}^{3}$, consists of high-density aggregates, such as those from diorite or diabase, and is usually used in structures that require larger mass, as for shielding radiation.

\subsection{Compressive strength}

One of the key properties measured in hardened concrete is the compressive strength because concrete is an excellent material when subjected to compressive stress, although it doesn't correspond as well when under tensile stress. The compressive strength is a good assessment used to measure the quality of concrete, but nowadays, only resistance cannot be considered the only reference to validate quality, because other destructive and nondestructive testing can be performed, even during the production process. There are several factors that influence the resistance to compression, such as concrete age (resistance increases with time); aggregates quality (good quality concrete materials result in good resistance), the water/cement factor (the higher the water content, the lower the specific resistance and the greater the plasticity). To perform axial compression test, it is necessary to extract evidence of a structure or to produce test specimens with standard dimensions during the application of concrete, being the second the most usual practice. Specimens are applied, in ages defined by the standard - typically 28 days, a uniformly distributed axial force across the cross-section until rupture, enabling the measurement of compressive strength.

\subsection{Dynamic elasticity module for resonant frequency}

The resonant frequency method, among dynamic or vibrations methods, consists of determining the fundamental resonant frequency of vibration of a sample. The continuous vibration is generated electromechanically and can, therefore, be used to calculate Young's modulus and Poisson's ratio. So it is necessary to know the principles ruling these vibratory systems and construction elements of its models, from which the indirect method of resonant frequency is part. (ALMEIDA, 2012).

The measurement and test methods for transverse, longitudinal and torsional resonant frequencies of concrete samples, by means of forced resonance or impact, serves to estimate the value of the dynamic specific modulus and other properties, being regulated by the American Standard Test Method for Fundamental Transverse, Longitudinal, and Torsional Frequencies of Concrete Specimens of the American Society for Testing and Materials (ASTM C 215, 2014). The British Standard Recommendations for the measurement of dynamic modulus of elasticity of the British Standards Institution (BS 1881: Part 209: 1990) also presents several recommendations on how to estimate the dynamic modulus of elasticity by the longitudinal resonant frequency.

\subsection{Electrical Resistivity of Concrete}

The electrical resistivity is a physical property that indicates the material's resistance to electric current flow, the performed tests can be destructive, with specimen extraction, and non-destructive with measurements on the surfaces of structures. These tests are related to durability and life cycle of concrete, also allowing the possibility of assessing the development of pathological manifestations.

According to Azarsa and Gupta (2017), the resistivity measurements of concrete can be accomplished by various techniques, nondestructively: using electrodes placed on a sample surface, or by placing a disc electrode, linear matrix or square matrix composed of four probes on the surface of concrete. Types of technical devices which can be normally used to measure resistivity physically, include: mass electrical resistivity test, disc surface test, Wenner four-points line matrix test, and four corners square matrix pattern test. In this work, the test with the method of two electrodes indicated by the NBR 9204 (ABNT, 2012), which presents the recommendations to determine the volume resistivity of hardened concrete, was carried out.

\section{EXPERIMENTAL PROCEDURES}

To develop this work, procedures recommended by the technical standards were used, and in the absence of a specific methodology for certain tests, we sought guidance on methodologies provided in technical literature.

\subsection{Materials}

The dosage and preparation of concrete specimens used in this research were initiated by the characterization of aggregates (sand and gravel). It was used Portland cement type CP V ARI, fine natural sand and grade 0 and 1 limestone nature gravel. 


\subsubsection{Binder}

Portland cement Type III (Brazilian denomination CP V) cement was selected because it contains at least $95 \%$ clinker and is cement with high initial and final resistances, manufactured in accordance to the requirements of NBR 16697 (ABNT, 2018) and reaches, on average, high resistance at 1 day old. Features clear and homogeneous hue by being derived from high purity limestone. The physical characteristics of this cement were provided by the manufacturer. The results are shown in Table 1 .

Table 1: Physical characteristics of the cement CPV ARI (Source: Lafarge Holcim (2018) - adapted)

\begin{tabular}{|c|c|c|c|}
\hline \multicolumn{2}{|c|}{ TYPE / CLASS CEMENT } & 3030 & Limit of NBR 16697:2018 \\
\hline Density $(\mathrm{kg} \mathrm{/} \mathrm{m})$ & Average & 4747 & $\geq 3000$ \\
\hline Blaine $\left(\mathrm{cm}^{2} / \mathrm{g}\right)($ specific area $)$ & Average & 2.1 & - \\
\hline Fineness \# 400 (\%) & Average & 131 & $\geq 60$ \\
\hline Setting Time Start (min) NBR 16606 & Average & 181 & $\leq 600$ \\
\hline Setting Time End (min) NBR 16606 & $\mathrm{R} 1$ day & 29.6 & $\geq 14.0$ \\
\hline \multirow{4}{*}{ Average Resistance to compression (MPa) } & R 3 days & 42.9 & $\geq 24.0$ \\
\cline { 2 - 4 } & R 7 days & 48.2 & $\geq 34.0$ \\
\cline { 2 - 4 } & R 28 days & 55.5 & - \\
\hline
\end{tabular}

\subsubsection{Aggregates}

The aggregates characterization tests are listed in Table 2, defining the characteristics of the materials to be used in the manufacture of concrete. The following tests were conducted: granulometric composition, sand fineness modulus and maximum characteristic diameter of gravel, density and unit weight of the aggregates and powdery materials content.

Table 2: Characteristics of aggregates

\begin{tabular}{|c|c|c|c|}
\hline Determinations & Sand & Gravel "0" & Gravel "1" \\
\hline Density $(\mathrm{kg} \mathrm{/} \mathrm{m})$ & 2590.67 & 2673.80 & 2673.80 \\
\hline Unit weight $(\mathrm{kg} \mathrm{/} \mathrm{m})$ & 1377.00 & 1400.00 & 1457.49 \\
\hline Fineness modulus & 2.0 & - & - \\
\hline Maximum feature size (mm) & 1.2 & 9.5 & 19.0 \\
\hline Pulverulent material content (\%) & 2.0 & - & - \\
\hline
\end{tabular}

\subsubsection{Water and additives}

Considering that concrete kneading water should not contain impurities, it was used drinking water provided by the local utility. To keep concrete fluid without the addition of water to its composition, it was decided to use the superplasticizer additive, which is an additive recommended for all types of concrete when the high reduction of kneading water is wanted with no change in setting time.

\subsection{Dosage}

The target is a conventional strength concrete ( $\mathrm{fck}=25 \mathrm{MPa}$ ), in which superplasticizer additive was used with the intention to improve the consistency of the concrete during mixing time. In Table 3 are presented the characteristics of the mixtures used.

Table 3: Recipe in mass

\begin{tabular}{|c|c|}
\hline \multicolumn{2}{|c|}{ Recipe used } \\
\hline Proportion & $1: 1.74: 1.58: 1.58: 0.60$ \\
\hline Cement & CP V ARI \\
\hline proportion of "0" and "1" & $50 \%$ and 50\% \\
\hline Sand & Fine \\
\hline Water/cement ratio & 0.60 \\
\hline fcj & $31.6 \mathrm{MPa}$ \\
\hline fck & $25.0 \mathrm{MPa}$ \\
\hline Flow & $190 \pm 20 \mathrm{~mm}$ \\
\hline Superplasticizer additive & $0.6 \%$ \\
\hline Mortar percentage & $51.65 \%$ \\
\hline
\end{tabular}

Mixing was carried out in a laboratory at $24 \pm 2^{\circ} \mathrm{C}$ temperature. As it consisted of an extended mixing case, the intention was to take the mixture to slump 0. The concrete was produced in a mixer, adopting the methodology used by (POLESELLO, 2012), who used in its research rest and agitation cycles in the concrete mixer in periods of 15 and 5 minutes, respectively, until the end of tests with fresh concrete. Considering the results presented in the research (POLESELLO, 2012), it was decided to set the initial slump of the mixture in $210 \mathrm{~mm}$ and the percentage of superplasticizer in $0.6 \%$ of the cement mass. Zero slump was obtained after 270 minutes from the start of mixing. 


\subsection{Performed Tests}

To evaluate the properties of the hardened concrete derived from prolonged mixing, for each mixing hour, four cylindrical specimens of $10 \mathrm{~cm}$ diameter and $20 \mathrm{~cm}$ height were molded in accordance with NBR 5738 (ABNT, 2015).

\subsubsection{Beginning and end of cement CP V ARI setting time test}

The test for the evaluation of the start and end of setting time realized during the research aimed to confirm the information provided by the manufacturer. The procedures were performed in accordance with the Brazilian standard NBR 16607 (ABNT, 2018), with the preparation of a normal consistency paste as recommended by NBR 16606 (ABNT, 2018). For this test, 500 g of cement was used and tests were performed in Vicat apparatus, as shown in Figure 1.

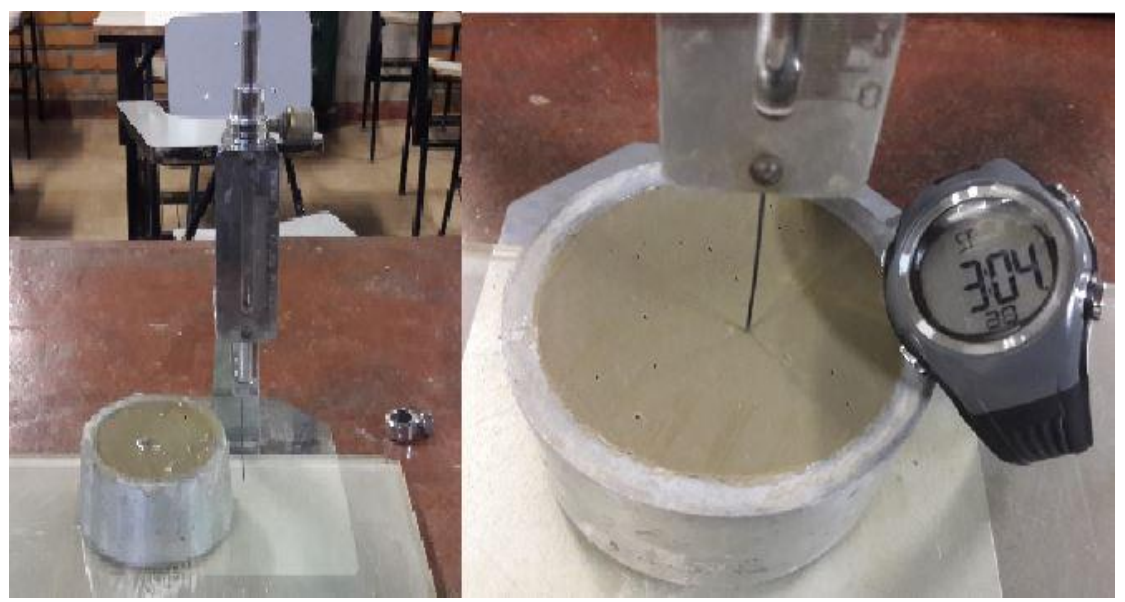

Figure 1: Setting time start and end test

\subsubsection{Slump test}

The monitoring of the concrete consistency during testing times was performed by the slump test, as shown in Figure 2, following the procedures recommended by NBR NM 67 (ABNT, 1998), this test was repeated every hour during the mixture to identify the null slump. This occurred at 270 minutes after the addition of the first water to concrete.

The loss of abatement can be overcome by adding extra water, additives and / or additions to the concrete mixture prior to discharge. This operation is known as a refresh. Although it is common to add more water to the mixture, it is undesirable because it causes a considerable loss of strength since the water/cement ratio increases significantly.

Despite the use of water with other chemicals to refresh the concrete may be convenient compared to the mere addition of water, in the concrete in question it is only used the superplasticizer without additional water, ie the concrete will be used exactly as rheological conditions are at the time of use.

Figure 2: Slump test

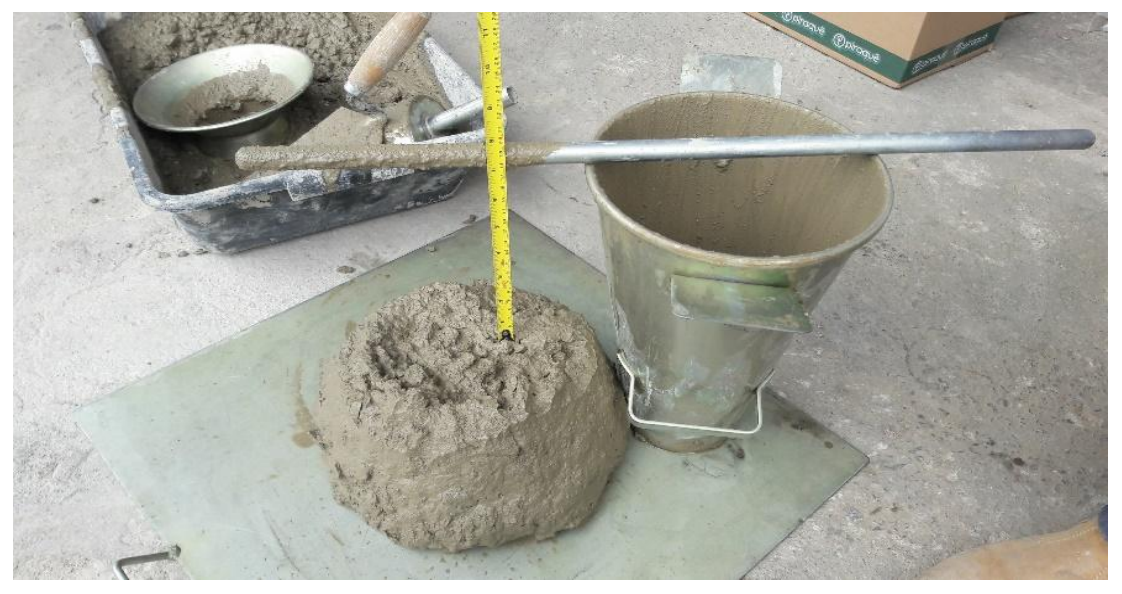

\subsubsection{Mixing temperature monitoring}

The temperature of the fresh concrete used in construction work must preferably be kept low, not exceeding $16{ }^{\circ} \mathrm{C}$, being acceptable an increase not exceeding $32{ }^{\circ} \mathrm{C}$. If the fresh concrete temperature cannot be controlled during mixing, it can be calculated from the temperature of its components (Neville and Brooks, 2013).

Tests were performed at an ambient temperature of $22{ }^{\circ} \mathrm{C}$ as shown in Figure 3, concrete temperature monitoring was performed every hour during mixing and as recorded in Table 5 it was noted that there was no significant increase in temperature of the concrete during mixing. 


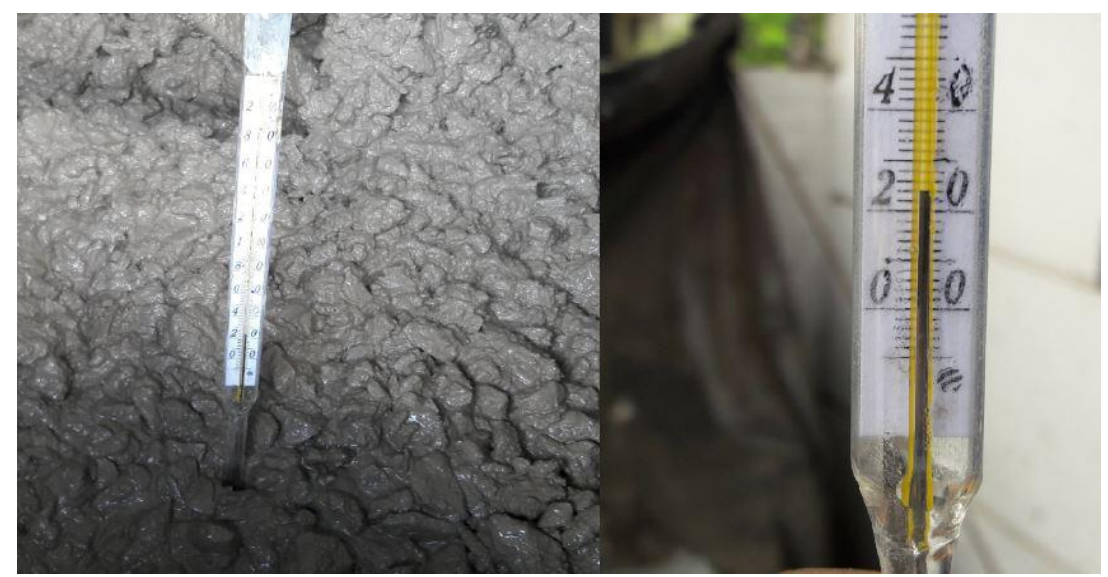

Figure 3: Monitoring the temperature of the mixture $\left(22^{\circ} \mathrm{C}\right)$

\subsubsection{Dynamic modulus}

The tests with the mean values of the dynamic modulus of elasticity were performed by the resonant frequency in the longitudinal mode, this test is governed by standards (ASTM C 215, 2008) (BS 1881: Part 209: 1990).

Erudite apparatus MKII Resonancy Frequency Test System Electronics CNS, shown in Figure 4, was used for determining the natural frequency of vibration of the concrete samples.

At the age of 28 days, measurements of resonant frequency were carried out, for each hour of research four specimens were evaluated. The resonant frequency was found as a function of sample length and type of material and the average of results for each researched mixing time are presented in Table 6.

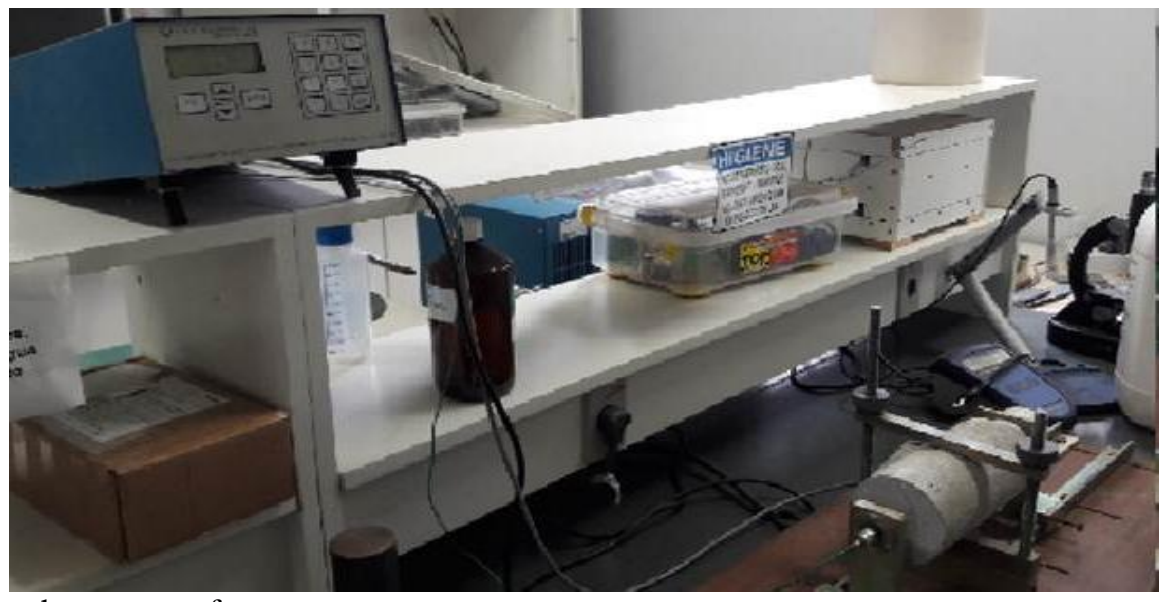

Figure 4: Equipment for the resonant frequency test

\subsubsection{Volumetric electrical resistivity}

The tests for determining the volumetric electrical resistivity were performed in the Special Testing Laboratory of the Department of Materials Engineering and Construction of UFMG (School of Engineering) in the equipment shown in Figure 5. The technical specifications of the equipment that compose the volume resistivity meter used in the study are presented in Table 4 .

Table 4: Characteristics of the equipment to determine the volumetric resistivity

\begin{tabular}{|c|c|}
\hline Tektronix equipment Brand & Voltage Generator - Politerm Brand \\
\hline Serial No. C065459 TDS 1012B & FG-8102 model 2MHz \\
\hline Voltage Range: $100-240 \mathrm{~V} \mathrm{115V}$ & Voltage 115V - 230V \\
\hline Frequency: 50-60Hz 400Hz & Sweep / Function Generator \\
\hline Max Power: 30 Watts & Fuse: $0.5 \mathrm{~A}, 0.2 \mathrm{~A} \mathrm{~F}$, F - PWR Max: 15W \\
\hline
\end{tabular}

Tests were performed in the laboratory at an ambient temperature of $25^{\circ} \mathrm{C}$ with relative humidity around $61 \%$. In accordance with NBR 9204 (ABNT, 2012), the samples were cured, and at the age of seven days had their edges rectified. With the intention to ensure adequate saturation of the specimens, they were placed in a tank with clean water, provided by the local utility, remaining submerged for a period of 48 hours. For the tests, it was set a frequency of $40 \mathrm{~Hz}$, amplitude of 5-10V and Chant resistance of $671.94 \Omega$. 
The means of electrical resistivity measurements of each mixing cycle are shown in Table 6 and the correlations between the compressive strength and the electrical resistivity are shown in the graph of Figure 7.

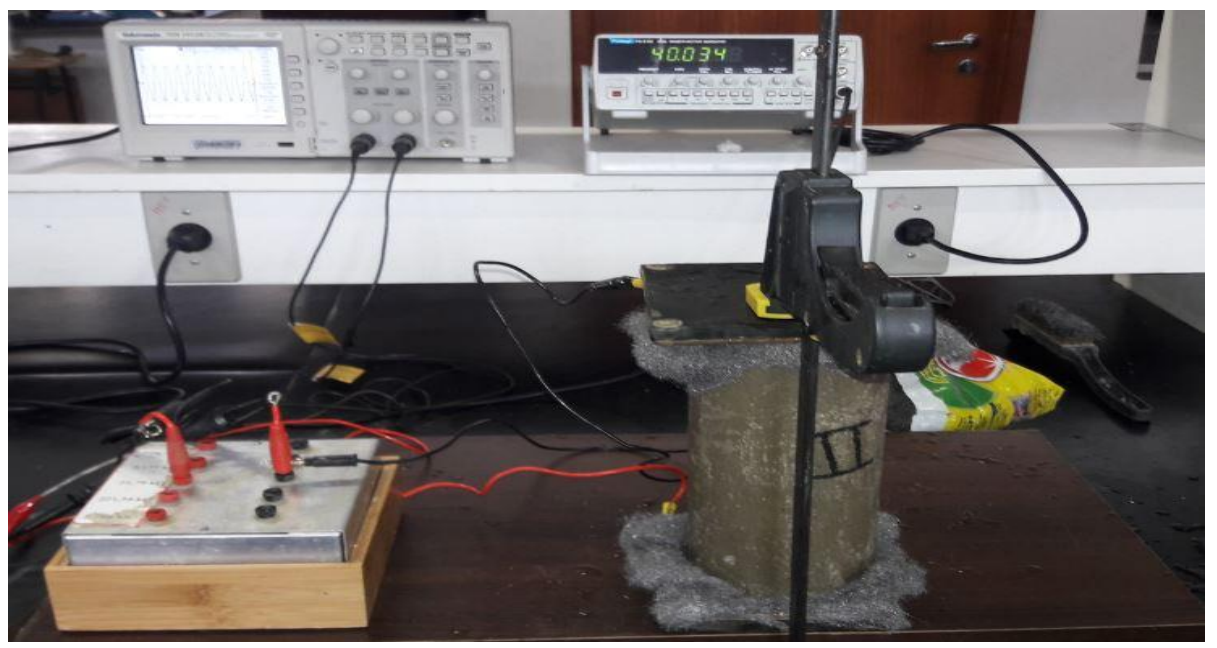

Figure 5: Equipment for testing volume resistivity of UFMG

\subsubsection{Evaluation of compressive strength}

At the age of 28 days, a total of twenty test samples were broken, four of which were molded after 15 minutes mixing and four more every hour until final four hours of mixing. The specimens were subjected to simple compression test in hydraulic press which has load capacity of $200 \mathrm{tf}$. The specimens were placed, one by one, between the compression plates in the vertical direction, parallel to the vertical axis of the machine as shown in Figure 6. According to NBR 5739 (ABNT, 2018), the results of the compressive strength of concrete are obtained by the continuously applied load $(0.45 \mathrm{MPa} / \mathrm{s})$ and without shocks.

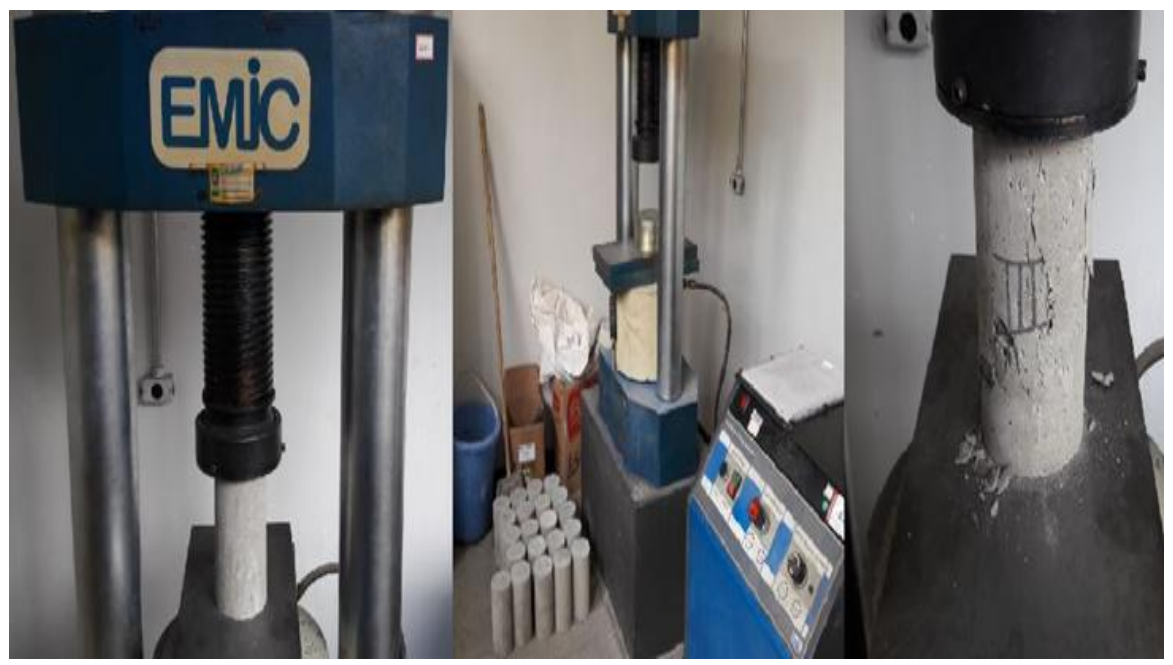

Figure 6: Press FDMS $200 \mathrm{tf}$

\section{RESULTS AND DISCUSSION}

One day prior to the mixture, start and end of cement setting time were measured obtaining, to a normal consistency paste of $33 \%, 133$ minutes setting time start and 184 minutes end, values which are very close to the provided by the cement manufacturer. The test results with the characteristics encountered during the production of fresh concrete in prolonged mixture are shown in Table 5. It was observed that there was a large loss of plasticity of fresh concrete during mixing, after 270 minutes of mixing, it was found that the concrete had zero slump, thus marking the end of the mixture. The temperature of the concrete was stable during the first two hours of mixing, after that period, there was a slight increase in temperature of $1^{\circ} \mathrm{C}$ maintained until the end of the test. A probable explanation for this increase is the beginning of cement setting time, which occurred at about 133 minutes after the start of mixing. 
Table 5: Characteristics of fresh concrete (cement CP VARI)

\begin{tabular}{|c|c|c|c|}
\hline $\begin{array}{c}\text { Mixing time } \\
(\text { minutes })\end{array}$ & $\begin{array}{c}\text { Slump } \\
(\mathrm{mm})\end{array}$ & $\begin{array}{c}\text { Temperature } \\
\left({ }^{\circ} \mathrm{C}\right)\end{array}$ & $\begin{array}{c}\text { Occurrence of the } \\
\text { setting time }\end{array}$ \\
\hline 15 & 210 & 22 & not \\
\hline 60 & 190 & 22 & not \\
\hline 120 & 130 & 22 & not \\
\hline 180 & 30 & 23 & yes \\
\hline 240 & 3 & 23 & yes \\
\hline 270 & 0 (null) & & 133 minutes \\
\hline \multicolumn{2}{|c|}{ Start of cement setting time } & 184 minutes \\
\hline
\end{tabular}

After 28 days of molding test specimens, tests to determine the main characteristics of the hardened concrete were performed. In Table 6, it is possible to observe the average results of the evaluation of the specific weight of the concrete, the elast ic modulus, compressive strength and volumetric resistivity. The specific mass of concrete had no significant change over time, but it can be observed that prolonged mixed concrete obtained slightly smaller values than those established for normal density concrete (about $2400 \mathrm{~kg} / \mathrm{m}^{3}$ ). The results for the dynamic modulus of elasticity and compressive strength showed that there was a gain of the average compressive strength and the value of the dynamic elastic modulus of concrete at the age of 28 days, this is explained by the fact of the loss of water verified in slump tests, motivating the reduction of the water/cement ratio during mixing.

Table 6: Results of tests at 28 days old - Cement CP V ARI

\begin{tabular}{|c|c|c|c|c|c|c|c|c|}
\hline \multirow{2}{*}{$\begin{array}{c}\text { Mixing } \\
\text { time } \\
\text { (Minutes) }\end{array}$} & \multicolumn{2}{|c|}{ Specific mass } & \multicolumn{2}{|c|}{ Dynamic modulus } & \multicolumn{2}{|c|}{ Compressive strength } & \multicolumn{2}{|c|}{ Volumetric resistivity } \\
\hline & $\begin{array}{c}(\mathrm{Kg} / \\
\left.\mathrm{m}^{3}\right)\end{array}$ & $\begin{array}{l}\text { Standard } \\
\text { deviation }\end{array}$ & $(\mathrm{GPa})$ & $\begin{array}{l}\text { Standard } \\
\text { deviation }\end{array}$ & $(\mathrm{MPa})$ & $\begin{array}{c}\text { Standard } \\
\text { deviation }\end{array}$ & $\begin{array}{c}(\mathrm{Ohm} \\
\mathrm{m})\end{array}$ & $\begin{array}{l}\text { Standard } \\
\text { deviation }\end{array}$ \\
\hline 15 & 2362.59 & 14.68 & 30,39 & 1.47 & 37.91 & 2.35 & 41.34 & 1.64 \\
\hline 60 & 2256.90 & 40.60 & 23.35 & 4.61 & 30.29 & 0.95 & 42.67 & 1.00 \\
\hline 120 & 2218.41 & 13.63 & 25.60 & 3.89 & 29.34 & 1.62 & 40.55 & 0.38 \\
\hline 180 & 2314.81 & 29.26 & 30.81 & 1.62 & 35.38 & 2.36 & 37.97 & 0.28 \\
\hline 240 & 2308.54 & 29.04 & 38.35 & 0.80 & 34.41 & 1.40 & 37.03 & 2.03 \\
\hline
\end{tabular}

The graphs shown in Figures 7 and 8 show the correlations observed between the compressive strength, modulus of elasticity and electrical resistivity in the course of the 240 minutes mixture for the dosage studied with the use of cement CP V ARI and superplasticizer without setting time inhibitor.

\section{Compressive Strength $\mathrm{x}$ Volumetric Electrical Resistivity}

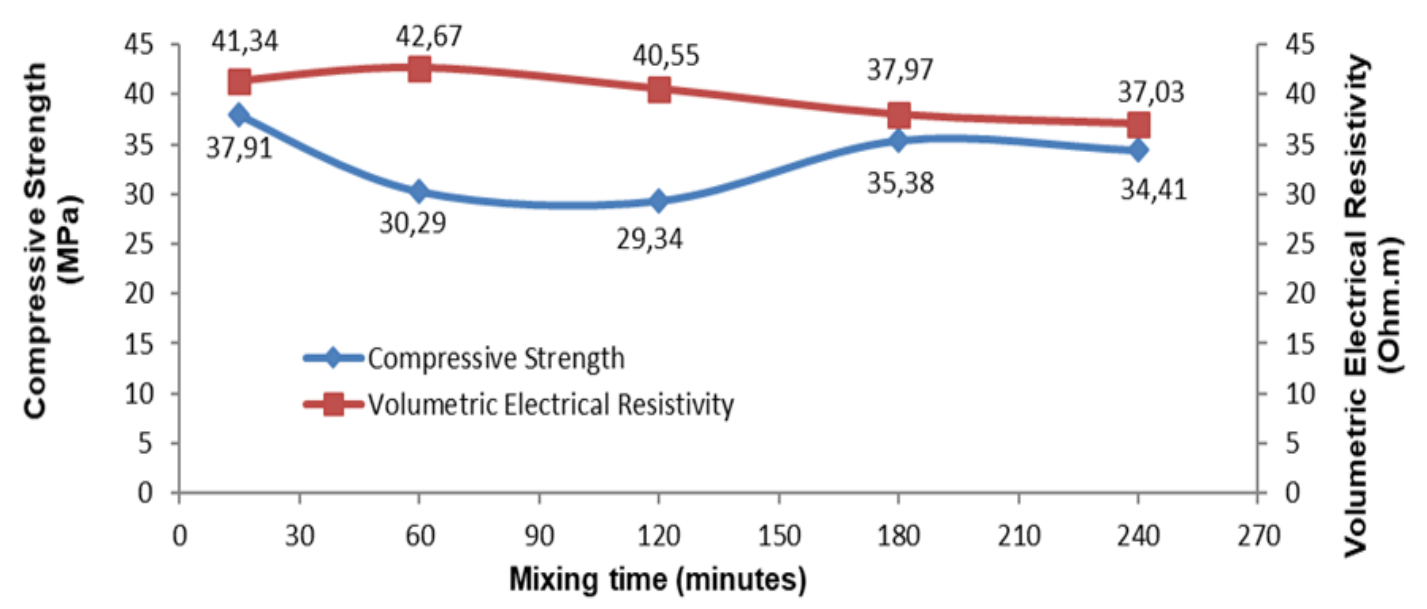

Figure 7: Correlation between compressive strength and the volumetric resistivity

In Figure 7 graph, it can be seen that while the mean resistance to compression to each studied time tends to remain above the expected value for the dosage, the volumetric resistivity tends to decrease for every mixing hour, having a value of $37,03 \Omega$.m at the end of 240 minutes. It is known that the fall of the electrical resistivity may indicate a more porous concrete and therefore less ability to protect steel from corrosion. 


\section{Compressive Strength $x$ Dynamic Modulus of Elasticity}

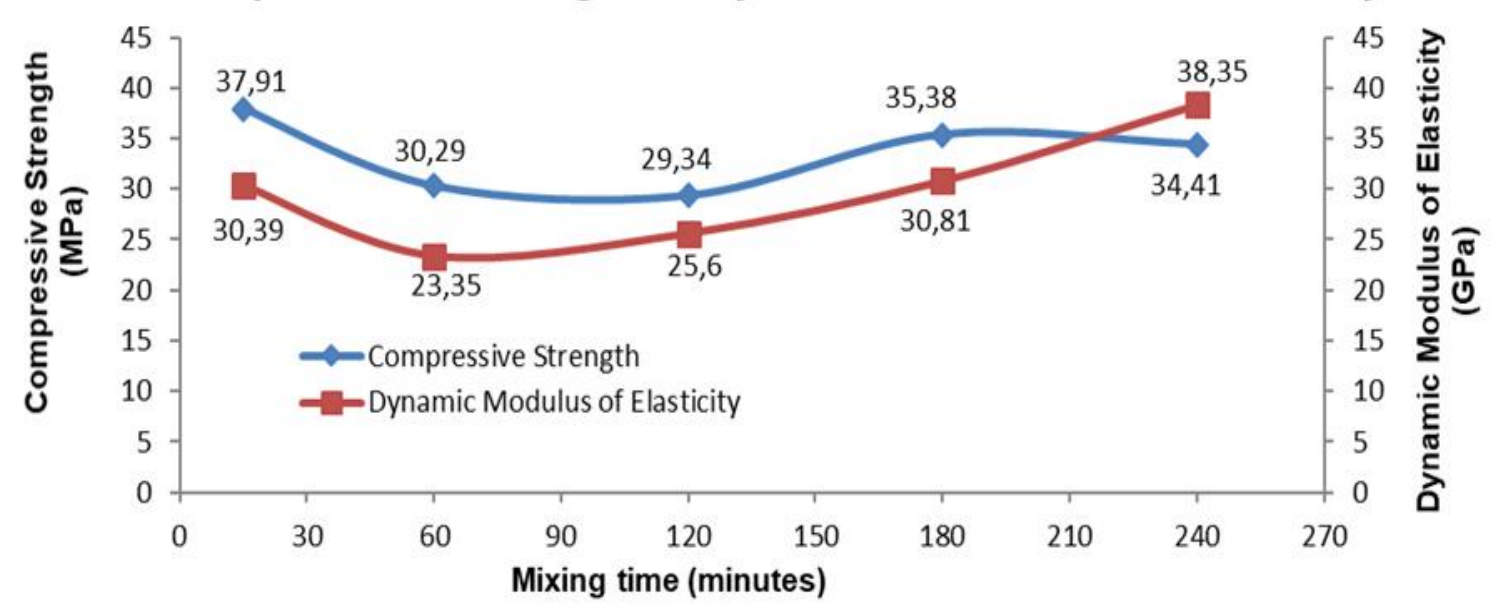

Figure 8: Correlation between compressive strength and dynamic modulus of elasticity

As shown in the graph of Figure 8, high values for tensile modulus and compressive strength were found for the first ruptured specimens, which were molded with 15 minutes mixing. There was still a reduction in these values in the first hour of test, but from that time on, it becomes clear that both the strength and the elasticity modulus show a tendency in an increase over the mixing time.

\section{CONCLUSIONS}

The reduction in slump observed for every mixing hour is justified by the evaporative water loss to the environment, which increases friction with the concrete in the inner parts of the mixer during the mixing time. It was also observed that the small increase in temperature registered during the concrete mixing occurred after the start of the cement setting time. Despite the difficulties of working with prolonged mixing concrete due to the significant loss of plasticity, it can be concluded that the water loss to the environment provides the reduction of the water/cement ratio, this fact generates no significant loss of resistance to compression and dynamic modulus of elasticity, but precautions should be taken against possible chemical attacks and assessments of the potential of reinforcement corrosion protected by prolonged mixing concrete should be done whenever possible, since electrical resistivity test showed that the higher the mixture time, the greater the propensity of reinforcement corrosion protected by prolonged mixed concrete. Finally, for cement CP V ARI using superplasticizer without setting time inhibitor and without the addition of water beyond provided in dosage, it can be proved that there were no significant loss of properties studied in prolonged mixing up to four hours, which proved the possibility of using this concrete, even with times above recommended by NBR 7212 (ABNT, 2012), provided care is taken to monitor the desired characteristics of the material, especially the potential of corrosion.

\section{REFERENCES}

ALMEIDA, S. M. D. Análise do módulo de elasticidade estático e dinâmico do concreto de cimento Portland através de ensaios de compressão simples e frequência ressonante. Belo Horizonte: UFMG, v. 1, 2012. Dissertação de Mestrado apresentada ao Programa de Pós-graduação em Construção Civil da Universiade Federal de Minas Gerais para obtenção do título de Mestre em Construção Civil.

ASSOCIAÇÃO BRASILEIRA DE NORMAS TÉCNICAS NBR 5738: Concreto - Procedimento para moldagem e cura de corpos de prova. Rio de Janeiro: ABNT, 2015 Versão Corrigida:2016.

NBR 5739: Concreto - Ensaios de compressão de corpos-de-prova cilíndricos. Rio de Janeiro: ABNT, 2018.

NBR 7212: Execução de Concreto Dosado em Centro - Procedimentos. Rio de Janeiro: ABNT, 2012.

NBR 9204: Concreto endurecido - Determinação da resistividade elétrica-volumétrica - Método de ensaio. Rio de Janeiro: ABNT, 2012.

NBR 16606: Cimento Portland - Determinação da pasta de consistência normal. Rio de Janeiro: ABNT, 2018.

NBR 16607: Cimento Portland - Determinação dos tempos de pega. Rio de Janeiro: ABNT, 2018.

NBR 16697: Cimento Portland - Requisitos. Rio de Janeiro: ABNT, 2018.

NBR NM 67: Concreto - Determinação da consistência pelo abatimento do tronco de cone: ABNT, 1988.

ASTM C94 / C94M-19a, Standard Specification for Ready-Mixed Concrete, ASTM International, West Conshohocken, PA, 2019, www.astm.org. DOI: 10.1520/C0094_C0094M-19a

ASTM C215-14, Standard Test Method for Fundamental Transverse, Longitudinal, and Torsional Resonant Frequencies of Concrete Specimens, ASTM International, West Conshohocken, PA, 2014, www.astm.org. DOI: 10.1520/C0215-14 
ARAÚJO, U. C.; GOULART, D. P.; OLIVEIRA, C. F. Avaliação da perda de desempenho de estrutura executada com concreto usinado vencido. Anais do XIII Congresso Internacional sobre Patologia e Reabilitação de Estruturas, Crato, 7-9 September 2017. 406 a 423.

AZARSA, P.; GUPTA, R. Electrical resistivity of concrete for durability evaluation: A review. Advances in Materials Science and Engineering, May 2017. 30.

BASKOCA, A.; OZKUL, M. H.; ARTIRMA, S. Effect of chemical admixtures on workability and strength properties of prolonged agitated concrete. Cemente and Concrete Research, USA, 17 February 1998. 737 - 747.

BS 1881: Part 209, 1990. Recommendations for the Measurement of Dynamic Modulus of Elasticity. Testing Concrete, British Standards Institution, London, UK.

Erdogdu, S. Effect of retempering with superplasticizer admixtures on slump loss and compressive strength of concrete subjected to prolonged mixing. Cement and Concrete Research 35 (2005) 907 - 912. DOI:10.1016/j.cemconres.2004.08.020

MEHTA, P. K.; MONTEIRO, P. J. M. Concreto: Microesturura, Propriedades e Materiais. 3 ed. ed. São Paulo: IBRACON, 2008.

NEVILLE, A. M.; BROOKS, J. J. Tecnologia do Concreto. Tradução de Ruy Alberto Creminini. $2^{\text {a }}$. ed. Porto Alegre: Bookman, v. 1, 2013. 448 p. ISBN ISBN 978-85-8260-071-9. Book.

PEREIRA, C. O que é Concreto Usinado? Escola Engenharia, 2017. Disponivel em: <https://www.escolaengenharia.com.br/co ncreto-usinado/>. Acesso em: 28 maio 2018.

POLESELlO, E. Avaliação da Resistência à Compressão e da Absorção de Água de Concretos Utilizados após o Tempo Máximo de Mistura e Transporte Especificado pela NBR 7212. Porto Alegre: UFRS, 2012. 141 p. Dissertação de mestrado apresentada ao Programa de Pós-Graduação em Engenharia Civil da Universidade Federal do Rio Grande do Sul.

RAHMAN, M. M. et al. Mixing time effects on properties of self compacting concrete. ARPN Journal of Engineering anda Applied Sciences, Vol. 6, n. 8, August 2011. 108 - 114.

URBAN, K., SICAKOVA, A. The Effect of Mixing Technique and Prolonged Mixing Time on Strength Characteristics of Concrete. Proceedings of Environment, Green Technology, and Engineering International Conference: Spain, 2018. DOI:10.3390/proceedings2201290 